\title{
ВЫДЕЛЕНИЕ И ФИЗИКО-ХИМИЧЕСКИЕ СВОЙСТВА ПЕКТИНОВЫХ ПОЛИСАХАРИДОВ ИЗ ЛИСТЬЕВ АМАРАНТА
}

\author{
С.Т. МИНЗАНОВА ${ }^{凶}$, В.Ф. МИРОНОВ 1 , А.3. МИНДУБАЕВ 1 ,

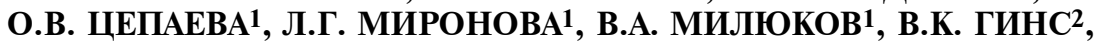 \\ М.С. ГИНС ${ }^{2}$, П.Ф. КОНОНКОВ 2 , В.М. БАБАЕВ ${ }^{1}$, В.Ф. ПИВОВАРОВ 2
}

Наряду с традиционными химическими сырьевыми ресурсами (нефть, газ, уголь) все большее значение приобретает растительное сырье. Растения - возобновляемый ресурс, они служат практически единственным источником ценных природных соединений - полисахаридов, которые имеют широкое применение в различных областях науки и техники. Особое место среди них занимает пектин, который входит в состав структурных элементов клеточной ткани высших растений и выполняет функции связывающих и упрочняющих компонентов клеточной стенки, а также регулирует водный обмен. Самым доступным источником пектина служат овощные растения. В настоящей работе впервые показано влияние характера гидролизующего агента и воздействия ультразвуком с частотой 22 кГц на эффективность гидролиза-экстракции и выход пектина из растений Amaranthus tricolor L. сорта Валентина в сравнении с классическим методом. Нашей целью была разработка способов выделения пектиновых полисахаридов из растений $A$. tricolor сорта Валентина, характеристика их физико-химических свойств и структурных особенностей. В экспериментах использовали высушенные листья овощного амаранта сорта Валентина селекции Всероссийского НИИ селекции и семеноводства овощных культур. Для исследования сахаров в боковых звеньях пектиновых полимеров проводили частичный гидролиз. Навеску образца гидролизовали трифторуксусной кислотой (ТФК) при $120{ }^{\circ} \mathrm{C}$ в течение 1 ч, затем ТФК отгоняли под вакуумом. Для определения моносахаридного состава навеску образца пектина гидролизовали 2 н. серной кислотой при $110{ }^{\circ} \mathrm{C}$ в течение 5 ч. Гидролизат нейтрализовали гидроксидом бария, осадок отделяли фильтрованием. Фильтраты исследовали методом бумажной хроматографии в системе н-бутанол:уксусная кислота:вода (5:1:4), проявляя хроматограмму анилинофталатным реактивом. Количественное содержание сахаров определяли на жидкостном хроматографe Shimadzu 20-AD Prominence («Shimadzu Corporation», Япония) с рефрактометрическим детектором Shimadzu RID-10A. Инфракрасные спектры были сняты на приборе IRS-113 («Bruker», Германия) с разрешением 1 см$^{-1}$ в диапазоне 400-4000 см-1 в таблетках КВr. Элементный состав определяли на элементном CHNSO-высокотемпературном анализаторе Euro EA 3028-HT-OM («EuroVector Instruments \& Software», Италия). Все измерения методом атомносиловой микроскопии (АCM) осуществляли на сканирующем зондовом микроскопе Multi Mode V («Veeco Instruments, Inc.», США) в прерывисто-контактном режиме. Была проведена серия экспериментов по выделению амарантина из листьев амаранта посредством водной экстракции с последующим экстрагированием пектиновых веществ. В качестве гидролизующих агентов на стадии гидролиза-экстракции использовали щавелевую и лимонную кислоты. Оптимизировали температуру, рН, гидромодуль и продолжительность обработки. С целью интенсификации переработки сырья использовали обработку на ультразвуковом дезинтеграторе УЗДН-1 (Россия). Структурное изучение выделенных полисахаридов методом инфракрасной спектрометрии показало их соответствие пектиновым веществам. Методом тонкослойной хроматографии установили, что в составе выделенных полисахаридных фракций значительную долю составляли полимеры арабинозы и галактозы (арабинаны и галактаны либо арабиногалактаны), а также присутствовали следы рамнозы. Методом бумажной хроматографии были получены аналогичные результаты. Согласно данным высокоэффективной жидкостной хроматографии, в пектиновых фракциях содержались глюкоза, галактоза, рамноза, арабиноза и галактуроновая кислота. Выявлено низкое содержание галактуроновой кислоты в гидролизате, полученном под действием как H2SO4, так и ТФК, - соответственно 0,63 и 1,68 \%. Установлены условия гидролиза-экстракции, обеспечивающие максимальный выход пектиновых веществ: 0,5 \% раствор щавелевой кислоты с комплексоном (0,5\% гексаметиленодиаминотетрауксусная кислота), 50-55 ${ }^{\circ} \mathrm{C}, 4$ ч, гидромодуль 1:15. После переосаждения этот образец пектина содержал интенсивную полосу поглощения валентных колебаний карбонилов карбоксильных групा и сложноэфирных групп в области 1742 см$^{-1}$. Данные термогравиметрии/дифференциально-сканирующей калориметрии (ТГ/ДСК) амарантового пектина указывали на двухступенчатую потерю массы. ИК-Фурье спектр газообразных продуктов термического разложения амарантового пектина показал, что вода была основным компонентом газовой фазы на первой стадии потери массы, на второй стадии происходило декарбоксилирование пектина. Максимальный размер агрегатов по данным атомно-силовой микроскопии составлял 2,4-2,5 мкм, минимальный $-\sim 330$ нм.

Ключевые слова: амарант, Amaranthus tricolor L., сорт Валентина, гидролиз-экстракция, 
ультразвуковой дезинтегратор, пектин, инфракрасная спектроскопия, термостабильность пектина, термогравиметрия/дифференциально-сканирующая калориметрия, ТГ/ДСК, атомно-силовая микроскопия.

Полисахариды - один из важнейших классов природных соединений, имеющих практическое применение в различных областях науки и техники. Особое место среди полисахаридов Amaranthus L. занимает пектин, который входит в состав структурных элементов клеточной ткани высших растений и выполняет функции связывающих и упрочняющих компонентов клеточной стенки, а также регулирует водный обмен (1). Пектиновые вещества широко применяются в медицине как детоксиканты тяжелых металлов и регуляторы обменных процессов в организме человека, а также служат универсальной пищевой добавкой (Е 440) (2). Несмотря на значительные объемы традиционных сырьевых ресурсов (яблочные и цитрусовые выжимки, свекловичный жом), идет поиск нового нетрадиционного сырья для производства пектинов и использования их при изготовлении функциональных пищевых продуктов (3-6). Культура амаранта благодаря высокой урожайности и высокому содержанию биологически активных веществ и антиоксидантов рассматривается как потенциальный источник ценных веществ растительного происхождения для медицины, сельского хозяйства и пищевой промышленности (7-9). В литературе описаны биоактивные пептиды, полученные из белков амаранта, проявляющие антимикробную, антиоксидантную и антигипертензивную активность (10-12). Сообщается также о гипохолестеринемическом эффекте пептидов (13) и их противоопухолевой активности (14).

Скрининг химического состава у растений амаранта различных видов показал, что его биомасса (листья, соцветия, стебли) содержит ряд химических соединений, представляющих практическую ценность. Это воска, каротиноиды, флавоноиды, белки, полисахариды и другие вещества. Определение их химического состава и разработка способов выделения открывают перспективы для получения продуктов функционального назначения $(6,16,17)$.

В настоящей работе впервые показано влияние характера гидролизующего агента и ультразвуковой обработки (частота 22 кГц) на эффективность гидролиза-экстракции и выход пектина при выделении из растений амаранта сорта Валентина в сравнении с классическим методом.

Нашей целью была разработка способов экстракции пектиновых полисахаридов из растений Amaranthus tricolor L. сорта Валентина и характеристика физико-химических свойств и структурных особенностей полученных соединений.

Методика. В экспериментах мы использовали высушенные листья овощного амаранта сорта Валентина селекции Всероссийского НИИ селекции и семеноводства овощных культур (ВНИИССОК), внесенного в Государственный реестр и разрешенного к промышленному использованию $(18,19)$. Растения выращивали на опытных полях ВНИИССОК (Московская обл.) без применения пестицидов и гербицидов.

В эксперименте 1100 г сухого измельченного сырья A. tricolor помещали в плоскодонную колбу, заливали дистиллированной водой с целью выделения пигмента амарантина и проводили экстракцию при комнатной температуре. Высушенное депигментированное сырье (85 г) заливали 0,5 \% раствором щавелевой кислоты, в экстрагирующую смесь добавляли комплексон - 0,5 \% гексаметиленодиаминотетрауксусную кислоту (ГДТК), связывающий ионы двухвалентных металлов. Экстракцию прово- 
дили в течение 4 ч при гидромодуле $1: 15$, pH 3,8 и температуре $50-55{ }^{\circ} \mathrm{C}$. Экстракт отделяли от жома фильтрацией, концентрат упаривали до 200 мл при $60{ }^{\circ} \mathrm{C}$ под вакуумом и осаждали ацетоном в соотношении 1:1. Осадок сушили в термошкафу SNOL 58/350 (АО «Умега», Литва) при 40-50 ${ }^{\circ} \mathrm{C}$, продукт (образец 1) получали в виде пленок. Масса высушенного пектинового полисахарида $-2,980$ г.

В эксперименте 2165 г сухого измельченного сырья помещали в плоскодонную колбу и заливали дистиллированной водой. К высушенному депигментированному сырью (108 г) добавляли 0,5\% раствор лимонной кислоты. Экстракцию проводили в отсутствие комплексона в течение 5 ч при гидромодуле $1: 14, \mathrm{pH} 3,8$ и температуре $50-55{ }^{\circ} \mathrm{C}$. Экстракт отделяли от жома на тканевом фильтре, фильтрат упаривали до 200 мл при $60{ }^{\circ} \mathrm{C}$ под вакуумом и осаждали ацетоном в соотношении $1: 1,5$. Осадок высушивали при температуре $40-50{ }^{\circ} \mathrm{C}$, масса высушенного осадка (образец 2) $-0,570$ г.

С целью интенсификации процесса гидролиз-экстракции в двух других экспериментах использовали ультразвуковую обработку на дезинтеграторе УЗДН-1 (Россия). Для этого из измельченных листьев амаранта (100 г) предварительно извлекали амарантин водой. Полученное депигментированное сырье делили на две части и в условиях ультразвукового воздействия проводили две экстракции - 1,0 \% щавелевой и 1,0\% лимонной кислотой.

В эксперименте 3 пектиновые вещества экстрагировали из растительного сырья (32 г) 1,0 \% щавелевой кислотой при ультразвуковой обработке (УЗДН-1, частота 22 кГц) в течение 5 мин при непрерывном подогреве (11-37 $\left.{ }^{\circ} \mathrm{C}\right)$ и гидромодуле 1:10. Экстракт отделяли фильтрованием с последуюшим центрифугированием (центрифуга Sigma 4-15, «SigmaAldrich», Германия). Продукт осаждали равным объемом ацетона, затем сушили при $60{ }^{\circ} \mathrm{C}$. Масса высушенного осадка (образец 3) $-0,420$ г.

В эксперименте 4 измельченное сырье (32 г) экстрагировали 1,0\% лимонной кислотой при обработке ультразвуком (УЗДН-1, частота 22 кГц) в течение 5 мин, непрерывном подогреве $\left(23-45^{\circ} \mathrm{C}\right)$ и гидромодуле $1: 10$. Отделенный от жома экстракт заливали равным объемом ацетона для осаждения пектиновых полисахаридов. Масса высушенного продукта (образец 4) - 0,560 г.

Выделенные пектиновые вещества очищали методом переосаждения с предварительной обработкой раствора ионообменной смолой (катионит КУ-2) с целью их деминерализации. Концентрацию пектина в экстрактах контролировали кальций-пектатным методом.

Для исследования сахаров в боковых звеньях пектиновых полимеров проводили частичный гидролиз. Навеску образца гидролизовали трифторуксусной кислотой (ТФК) при $120{ }^{\circ} \mathrm{C}$ в течение 1 ч, затем ТФК отгоняли под вакуумом. Для определения моносахаридного состава навеску образца пектина гидролизовали 2 н. серной кислотой при $110{ }^{\circ} \mathrm{C}$ в течение 5 ч. Гидролизат нейтрализовали гидроксидом бария, осадок отделяли фильтрованием. Фильтраты исследовали методом бумажной хроматографии в системе н-бутанол:уксусная кислота:вода (5:1:4), проявляя хроматограмму анилинофталатным реактивом. Бумажную хроматографию осуществляли на хроматографической бумаге ЗММ (Чехия), тонкослойную - на пластинках Silufol UV-254 («Kavalier», Чехия) в системе н-бутанол:уксусная кислота:вода $(5: 4: 1)$. В качестве проявителя использовали анилинфталат, метчиков - моносахариды («Sigma-Aldrich», Германия). 
Количественное содержание сахаров определяли на жидкостном хроматографе Shimadzu 20-AD Prominence («Shimadzu Corporation», Япония) с рефрактометрическим детектором Shimadzu RID-10A. Использовали хроматографические колонки ReproSil-Pur NH2 (250 × 4 мм) («Dr. Masch Gmbh», Германия) и YMC-Pack Polyamine II $(250 \times 4,6$ мм) («YMC Europe Gmbh», Германия). В качестве подвижной фазы применяли элюент ацетонитрил:вода 75:25 (по объему), скорость подачи элюента 1 мл/мин. Калибровка проводилась по стандартным растворам моносахаридов («Sigта», Германия).

Инфракрасные спектры были сняты на приборе IRS-113 («Bruker», Германия) с разрешением 1 см$^{-1}$ в диапазоне 400-4000 cm$^{-1}$ в таблетках $\mathrm{KBr}$. Элементный состав определяли на элементном CHNSO-высокотемпературном анализаторе Euro EA 3028-НT-OM («EuroVector Instruments \& Software», Италия), стандартом служил стрептоцид (C $-41,85 \%, \mathrm{H}-$ $4,65 \%, \mathrm{~N}-16,26 \%, \mathrm{~S}-18,62 \%)$.

Все измерения методом атомно-силовой микроскопии (АСM) проводили на сканирующем зондовом микроскопе Multi Mode V («Veeco Instruments, Inc.», США) в прерывисто-контактном режиме. При сканировании использовали прямоугольные кантилеверы RTESP («Veeco Instruments, Inc.», США) с силиконовыми зондами. Резонансная частота кантилеверов приходилась на область 250-350 кГц, радиус кривизны зонда составлял 10-13 нм. Микроскопические изображения получались с разрешением $512 \times 512$ точек на кадр при скорости сканирования 1 Гц. Для устранения искажений, связанных с «дрожанием» микроскопа под действием внешних шумов, применяли антивибрационную систему («ТМС Vibration control», США), способную сглаживать колебания с частотой до 0,5 Гц (нижняя граница). Препараты готовили нанесением 7 мкл пектинового раствора на подложку из слюды с последующим осаждением на нее частиц пектина.

Ультрафильтрацию проводили на автоматизированной ультрафильтрационной установке АУФ-0.6 (ТОО «Взор», Россия) с полыми волокнами. Граница фильтрации - 50 кДа, рабочее давление при фильтрации 0,8-1,2 МПа, площадь фильтрующей поверхности - $200 \mathrm{~cm}^{2}$.

Для исследования термического разложения амарантового пектина применили метод синхронного термического анализа - термогравиметрию/дифференциальную сканирующую калориметрию с ИК-Фурье спектроскопией (ТГ/ДСК), при котором регистрируется изменение массы образца в зависимости от температуры с соответствующими тепловыми эффектами. Использовали сопряженную систему из прибора синхронного термического анализа ТГ/ДСK STA449-F3 («Netzsch», Германия) и ИКФурье спектрометра Tensor 27 («Bruker», Германия).

Результаты. Мы провели серию экспериментов по выделению амарантина из листьев амаранта сорта Валентина посредством водной экстракции с последующим экстрагированием пектиновых веществ. В качестве гидролизующих агентов на стадии гидролиза-экстракции использовали щавелевую и лимонную кислоты. Были оптимизированы следующие технологические параметры: температура, $\mathrm{pH}$, гидромодуль и продолжительность обработки. С целью интенсификации процесса применяли ультразвуковую обработку. Условия режима экстрагирования и выход пектинов приведены в таблице 1.

Согласно полученным результатам, обработка на ультразвуковой установке УЗДН-1 позволила существенно сократить продолжительность экстракции. Кроме того, при использовании лимонной кислоты масса вы- 
деленных пектиновых полисахаридов оказалась выше, чем при экстракции щавелевой (см. табл. 1). Возможно, это различие связано с условиями экстракции: образец с лимонной кислотой перед обработкой на УЗДН-1 был подогрет до температуры $20{ }^{\circ} \mathrm{C}$.

1. Условия выделения пектина из фитомассы растений амаранта (Amaranthus tricolor L.) сорта Валентина посредством кислотного гидролиза

\begin{tabular}{|c|c|c|c|c|c|c|}
\hline \multirow[b]{2}{*}{ Гидролизующий агент } & \multicolumn{4}{|c|}{ Условия экстракции } & \multirow{2}{*}{$\begin{array}{l}\text { Масса } \\
\text { пектина, г }\end{array}$} & \multirow{2}{*}{$\begin{array}{l}\text { Выход (на } \\
\text { АСМ сырья), \% }\end{array}$} \\
\hline & $\begin{array}{l}\text { продолжи- } \\
\text { тельность }\end{array}$ & $\mathrm{T},{ }^{\circ} \mathrm{C}$ & $\begin{array}{l}\text { гидро- } \\
\text { модуль }\end{array}$ & \begin{tabular}{|l|} 
частота, \\
кГц
\end{tabular} & & \\
\hline $\begin{array}{l}0,5 \% \text { раствор щавелевой } \\
\text { кислоты }+0,5 \% \text { ГДТК }\end{array}$ & 4 ч & $50-55$ & $1: 15$ & - & 2,98 & 3,51 \\
\hline $\begin{array}{l}\text { кислоты } \\
1,0 \% \text { раствор щавелевой }\end{array}$ & 5 ч & $50-55$ & $1: 14$ & - & 0,57 & 0,53 \\
\hline $\begin{array}{l}\text { кислоты } \\
1,0 \% \text { раствор лимонной }\end{array}$ & 5 мин & $11-37$ & $1: 10$ & 22 & 0,42 & 0,63 \\
\hline кислоты & 5 мин & $23-45$ & $1: 10$ & 22 & 0,56 & 1,75 \\
\hline
\end{tabular}

Были исследованы физико-химические характеристики и структурные особенности пектиновых веществ, полученных из амаранта сорта Валентина. Элементный анализ (C $-41,87 \%, \mathrm{H}-6,56 \%)$ показал отсутствие белка при экстракции 0,5 \% щавелевой кислотой с добавлением комплексона $(0,5 \%$ ГДТК) и высокое содержание белка $(\mathrm{N}-4,43 \%)$ при экстракции $0,5 \%$ лимонной кислотой. В образцах, полученных в условиях ультразвуковой обработки, при экстракции как $0,5 \%$ щавелевой кислотой, так и $0,5 \%$ лимонной кислотой содержание азота составило $2,0 \%$.

Для определения моносахаридного состава провели гидролиз образцов выделенного пектина 2 н. серной кислотой и частичный гидролиз ТФК. Методом тонкослойной хроматографии установили, что в составе выделенных полисахаридных фракций значительную долю составляли полимеры арабинозы и галактозы (арабинаны и галактаны либо арабиногалактаны), а также присутствовали следы рамнозы. Согласно данным высокоэффективной жидкостной хроматографии, в пектиновых фракциях содержались глюкоза, галактоза, рамноза, арабиноза и галактуроновая кислота в соотношении 8,3:7,7:4,1:6,6:71,0, что согласуется с исследованиями R. Sarkar c соавт. (20). Выявлено низкое содержание галактуроновой кислоты в гидролизате, полученном под действием как $\mathrm{H}_{2} \mathrm{SO}_{4}$, так и ТФК, соответственно 0,63 и 1,68 \%. В варианте с экстракцией $0,5 \%$ щавелевой кислотой с ГДТК рамнозу не обнаружили. Методом бумажной хроматографии получили аналогичные результаты.

Инфракрасная спектроскопия (ИКС) - один из распространенных методов исследования растительных полисахаридов (21). Его используют как для мониторинга экстрактов, так и для количественного определения кислых и нейтральных сахаров в полисахариде. Структурное изучение выделенных полисахаридов методом ИКС показало их соответствие пектиновым веществам (табл. 2). В представленных ИК-спектрах в области 3000-3600 см-1 для всех образцов наблюдалась широкая интенсивная полоса, характерная для валентных колебаний гидроксильных групп. Характерный сдвиг свидетельствовал о том, что это полоса валентных колебаний групп -ОН с водородной связью. Также было показано, что в ИКспектрах пектиновых веществ присутствовали характерные полосы поглощения различной интенсивности в области частот $1700-1750 \mathrm{~cm}^{-1}$, соответствующие валентным колебаниям карбонилов карбоксильных групп, и 
сложноэфирных групп в области $1730-1750 \mathrm{~cm}^{-1}$.

В области частот 1632-1647 $\mathrm{cm}^{-1}$ наблюдались полосы поглощения, соответствующие валентным колебаниям диссоциированных карбоксильных групп. Полосы поглощения в области 1020-1100 $\mathrm{cm}^{-1}$ соответствовали валентным колебаниям пиранозных циклов, а полосы при $1325 \mathrm{~cm}^{-1}$ плоскостным колебаниям групп - СН (ИК-спектры пектинов из фитомассы растений амаранта сорта Валентина, полученных посредством кислотного гидролиза, см. на http://www.agrobiology.ru).

2. Положение максимумов $\left(\mathrm{cm}^{-1}\right)$ основных характеристичных полос поглощения в инфракрасных спектрах образцов пектина, полученных кислотным гидролизом из растений амаранта (Amaranthus tricolor L.) сорта Валентина (ИК-Фурье спектрометр IRS-113, «Bruker», Германия)

\begin{tabular}{cccccc}
\hline Образец 1 & Образец 2 & Образец 3 & Образец 4 & Преимущественные типы колебаний \\
\hline 3444 & 3445 & 3427 & 3412 & $v(\mathrm{OH}), v\left(\mathrm{H}_{2} \mathrm{O}\right)$ \\
2925 & 2923 & 2924 & 2921 & $v(\mathrm{CH})$ \\
1739 & 1738 & - & - & $v(\mathrm{C}=\mathrm{O})$ \\
1634 & 1632 & 1647 & 1647 & $v(\mathrm{COO}-)$ \\
1401 & 1406 & 1402 & 1403 & $v, \delta(\mathrm{C}-\mathrm{OH})$ \\
1382,1228 & 1238 & 1325,1224 & $1375,1325,1294$ & $\delta(\mathrm{CH})$ \\
$1022-1101$ & $1022-1104$ & 1029 & $1029-1155$ & $v(\mathrm{C}-\mathrm{O}-\mathrm{C}), v(\mathrm{C}-\mathrm{C}), v(\mathrm{C}-\mathrm{O})$
\end{tabular}

П р и м е ч а н и е. Описание методики получения образцов см. в разделе «Методика». Прочерки означают отсутствие соответствующих пиков.

При экстракции без обработки ультразвуком наибольшую степень этерификации имел пектин, полученный с использованием $0,5 \%$ раствора щавелевой кислоты с 0,5 \% ГДТК. В образцах пектина, выделенных с обработкой на УЗДН-1, преобладали солевые карбоксилы (образец со щавелевой кислотой также содержал минорное количество свободных карбоксильных групп). В обоих образцах присутствовала полоса $1325 \mathrm{~cm}^{-1}$ (в образце с лимонной кислотой она была выражена ярче), соответствующая деформационным плоскостным колебаниям групп -СН. Во всех экспериментах кроме полисахаридов экстрагировались белки, а в ИК-спектрах были обнаружены полосы поглощения амидных групп.

Максимальный выход пектина обеспечивало использование в качестве гидролизующего агента $0,5 \%$ раствора щавелевой кислоты с 0,5\% ГДТК. В связи с этим пектин $A$. tricolor сорта Валентина, полученный указанным способом (образец 1), был дополнительно очищен переосаждением этиловым спиртом и охарактеризован методами ИК-спектроскопии, ТГ/ДСК и АСМ.

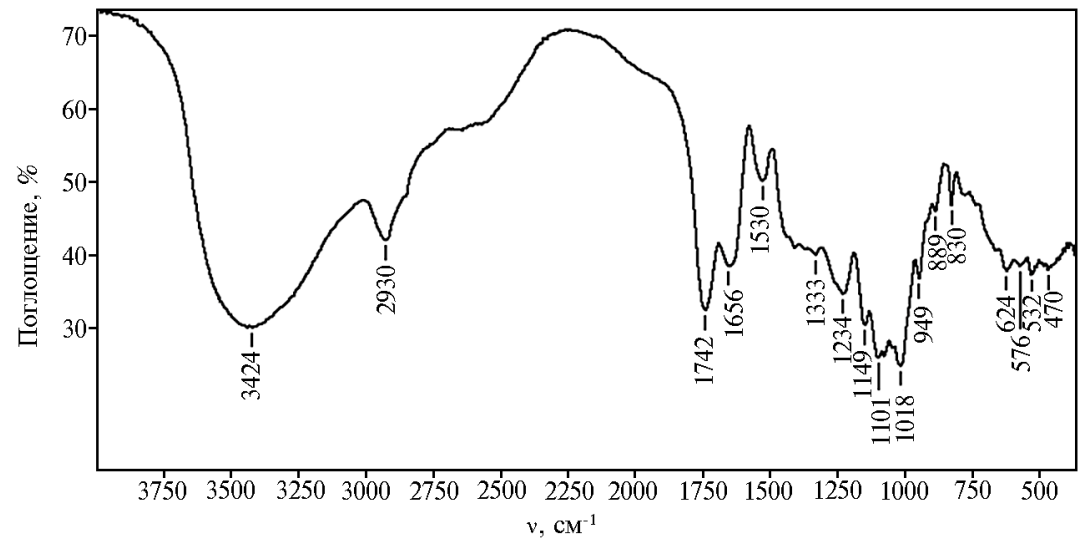

Рис. 1. Инфракрасный спектр пектина, выделенного из растений амаранта (Amaranthus tricolor L.) сорта Валентина кислотным гидролизом $(0,5 \%$ раствор щавелевой кислоты $+0,5 \%$ гексаметиленодиаминотетрауксусная кислота) и дополнительно очищенного переосаждением этиловым спиртом (ИК-Фурье спектрометр Tensor 27, «Bruker», Германия). 
После переосаждения этот образец пектина имел интенсивную полосу поглощения валентных колебаний карбонилов карбоксильных групп и сложноэфирных групп в области $1742 \mathrm{~cm}^{-1}$ (рис. 1).

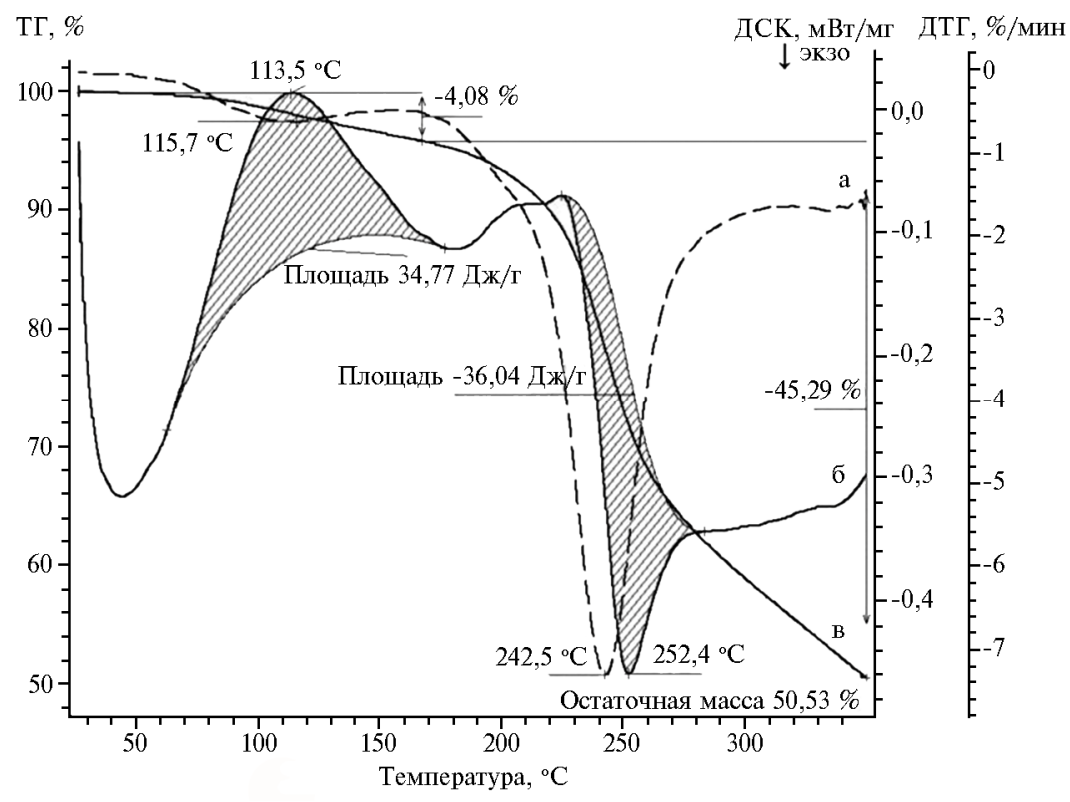

Рис. 2. Кривые, полученные в результате термогравиметрии/дифференциальной сканирующей калориметрии (ТГ/ДСК) пектина, выделенного из растений амаранта (Amaranthus tricolor L.) сорта Валентина кислотным гидролизом $(0,5 \%$ раствор щавелевой кислоты $+0,5 \%$ гексаметиленодиаминотетрауксусная кислота) и дополнительно очищенного переосаждением этиловым спиртом: а - кривая Грама-Шмидта, б - ДСК, в - ТГ. Измерение проводили на приборе синхронного термического анализа STA449-F3 («Netzsch», Германия), совмещенном с ИКФурье спектрометром Tensor 27 («Bruker», Германия).

Термостабильность пектинов - одна из важнейших характеристик, определяющая условия их хранения и применения в кондитерской промышленности. Данные ТГ/ДСК пектина, который мы выделили из амаранта сорта Валентина (образец 1) и дополнительно очистили переосаждением этиловым спиртом, указывали на двухступенчатую потерю массы. Первая стадия имела пик при $117,3{ }^{\circ} \mathrm{C}$ с потерей массы на кривой ТГ $\sim 4,1 \%$ и сопровождалась эндотермическим пиком при $113,5{ }^{\circ} \mathrm{C}$. Затем при $243,1{ }^{\circ} \mathrm{C}$ наблюдалась вторая стадия потери массы $(\sim 45,3 \%)$ совместно с экзотермическим пиком с энтальпией, которая оценивалась в 36,04 Дж/г (рис. 2). ИК-Фурье спектр газообразных продуктов термического разложения амарантового пектина показал, что вода была основным компонентом газовой фазы на первой стадии потери массы, на второй стадии происходило декарбоксилирование пектина.
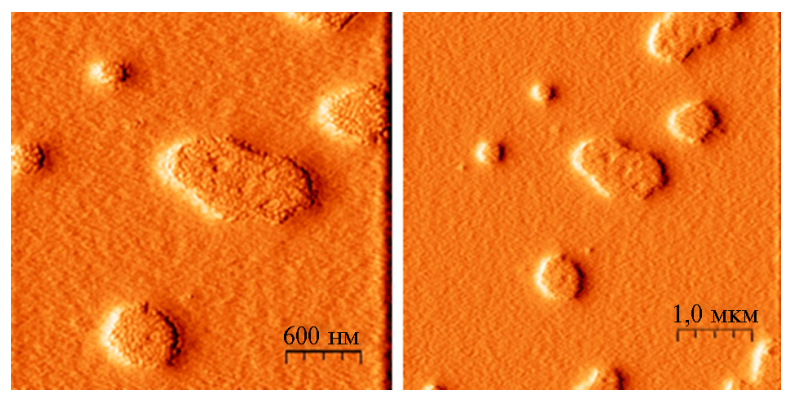

Рис. 3. Изображение поверхности пектина, полученного кислотным гидролизом $(0,5 \%$ раствор щавелевой кислоты $+0,5 \%$ гексаметиленодиаминотетрауксусная кислота) из растений амаранта (Amaranthus tricolor L.) сорта Валентина и дополнительно очищенного переосаждением этиловым спиртом (метод атомно-силовой микроскопии, сканирующий зондовый микроскоп Multi Mode V, «Veeco Instruments Inc.», США). 
Растворы пектина A. tricolor сорта Валентина (образец 1), дополнительно очищенного переосаждением этиловым спиртом (концентрация растворов $10^{-4} \%$ ), исследовали методом АСМ (рис. 3). Максимальный размер агрегатов составлял 2,4-2,5 мкм, минимальный - 330 нм. Наиболее часто встречались агрегаты с размерами от 660 до 880 нм, размер отдельных частиц, из которых состояли агрегаты, составлял 30-45 нм.

Полученные нами результаты по выходу пектина из фитомассы A. tricolor сорта Валентина в расчете на абсолютно сухую массу сырья и физико-химическим свойствам продукта представляют практический интерес для его масштабного производства, востребованного в пищевой промышленности и фармакологии. Ухудшение экологической обстановки и рост числа различных заболеваний обусловливают необходимость в детоксицирующих препаратах и эффективных лекарственных средствах пролонгированного действия на основе пектиновых полисахаридов. Из литературных источников известно, что амарантовые пектины обладают широким спектром физиологической активности $(22,23)$.

Традиционная технология получения пектина широко использует способ гидролиза протопектина сильными минеральными кислотами. В настоящее время основным экстрагирующим растворителем для высвобождения пектина из тканей растений служит соляная кислота ( $\mathrm{HCl})$. Однако использование минеральных кислот создает проблемы для окружающей среды $(5,9)$. Современное научное направление «зеленая химия» (Green Chemistry) предусматривает разработку принципиально новых подходов к моделированию процессов и технологических систем, снижающих антропогенную нагрузку на окружающую среду и не оказывающих вредного воздействия на человека. Е.-Н. Сhо с соавт. (24) для повышения экологичности производства экстрагировали пектин из яблочных выжимок органическими кислотами (винная, яблочная, лимонная) при 85 С. Выделенные пектины были высокоэтерифицированными и высокомолекулярными, максимальную молекулярную массу отмечали при использовании лимонной кислоты. Выход пектинов, экстрагированных органическими кислотами, был сопоставим с таковым при экстракции 0,1 М соляной кислотой, широко применяемой для этих целей в промышленности. Результаты авторов подтверждают перспективность и эффективность использования органических кислот в качестве гидролизующего агента и согласуются с выбором щавелевой и лимонной кислоты в наших исследованиях для разработки способа получения пектина из фитомассы амаранта A. tricolor сорта Валентина.

Необходимо отметить, что извлечение пектина из нетрадиционного сырья требует тщательной доработки существующих технологий, включающей не только изменение параметров проведения основных стадий, но и поиск дополнительных этапов воздействия на сырье и получаемый продукт с целью повышения его качества. Существует технология, основанная на использовании в качестве гидролизующего агента электроактивированной воды, полученной методом электродиализа. Разработаны экологически чистые технологии получения пектина, основанные на применении роторно-пульсационных аппаратов и ультразвуковых диспергаторов, позволяющих интенсифицировать процессы гидролиза-экстракции пектинсодержащего сырья и при этом заменить традиционно используемые сильные минеральные кислоты на «мягкие» пищевые (25). Кроме того, существует технология, основанная на использовании микроволнового излучения (26). J.P. Maran с соавт. (27) предложили оптимальные условия экс- 
тракции с помощью микроволн, обеспечивающие максимальный выход пектина (28,86 \%): мощность микроволн 413 Вт, рН 2,7, продолжительность 134 с, гидромодуль 1:18.

Таким образом, эффективность гидролиза-экстракции пектиновых веществ зависит от характера гидролизующего агента и следующих основных факторов: рН среды, гидромодуль, продолжительность и температура. Нами предложены условия гидролиза-экстракции, обеспечивающие максимальный выход $(3,51 \%)$ пектиновых веществ при выделении из растения Amaranthus tricolor L. сорта Валентина с применением классического метода: $0,5 \%$ раствор щавелевой кислоты с комплексоном $(0,5 \%$ гексаметиленодиаминотетрауксусная кислота), 50-55 ${ }^{\circ} \mathrm{C}, 4$ ч, гидромодуль 1:15. Ультразвуковая обработка при частоте 22 кГц позволила сократить продолжительность экстракции с 4 ч до 5 мин, обеспечивая выход пектина $1,75 \%$. Структурное изучение выделенных полисахаридов методом инфракрасной спектрометрии показало их соответствие пектиновым веществам. Методом высокоэффективной жидкостной хроматографии установлено, что в пектиновых фракциях содержались моносахариды глюкоза, галактоза, рамноза, арабиноза и галактуроновая кислота. Содержание галактуроновой кислоты в гидролизате, полученном действием $\mathrm{H}_{2} \mathrm{SO}_{4}$, составляло $0,63 \%$, а в гидролизате, полученном с трифторуксусной кислотой, $1,68 \%$. Физико-химические свойства исследованных пектинов из амаранта сорта Валентина (высокая молекулярная масса и степень этерификации) позволяют рекомендовать их для пищевой промышленности.

\footnotetext{
${ }^{1}$ Институт органической и физической химии им. А.Е. Арбузова - обособленное структурное подразделение ФИЦ Казанский научный центр РАН, 420088 Россия, Республика Татарстан, г. Казань, ул. Арбузова, 8, e-mail: minzanova@iopc.ru $\bowtie$, mironov@iopc.ru, mindubaev-az@yandex.ru, tsepaeva@iopc.ru, liubov.mironova@iopc.ru,miluykov@iopc.ru, babaev@iopc.ru;

2 ФГБНУ Федеральный научный иентр овощеводства, 143080 Россия, Московская обл., Одинцовский р-н, пос. ВНИИССОК, ул. Селекционная, 14,

e-mail: anirr@bk.ru, anirr67@yandex.ru, pivovarov@vniissok.ru
}

Sel'skokhozyaistvennaya biologiya [Agricultural Biology], 2021, V. 56, № 3, pp. 591-601

\title{
EXTRACTION AND PHYSICOCHEMICAL CHARACTERIZATION OF PECTIN POLYSACCHARIDES FROM AMARANTH LEAVES
}

\author{
S.T. Minzanova ${ }^{\boxplus}$, V.F. Mironov ${ }^{1}$, A.Z. Mindubaev ${ }^{1}$, O.V. Tsepaeval, L.G. Mironova ${ }^{1}$, \\ V.A. Milyukov', V.K. Gins', M.S. Gins', P.F. Kononkov', V.M. Babayev', V.F. Pivovarov'
}

${ }^{1}$ Arbuzov Institute of Organic and Physical Chemistry, FRC Kazan Scientific Center RAS, 8, ul. Arbuzova, Kazan, Republic of Tatarstan, 420088 Russia, e-mail minzanova@iopc.ru (corresponding author $\varangle$ ), mironov@iopc.ru, mindubaev-az@yandex.ru, tsepaeva@iopc.ru, liubov.mironova@iopc.ru, miluykov@iopc.ru, babaev@iopc.ru;

${ }^{2}$ Federal Research Center for Vegetable Growing, 14, ul. Selektsionnaya, pos. VNIISSOK, Odintsovskii Region, Moscow Province, 143080 Russia, e-mail anirr@bk.ru, anirr67@yandex.ru, pivovarov@vniissok.ru ORCID:

Minzanova S.T. orcid.org/0000-0001-9678-8821 Mironov V.F. orcid.org/0000-0002-4198-3774 Mindubaev A.Z. orcid.org/0000-0002-8596-7805 Tsepaeva O.V. orcid.org/0000-0003-0952-0486 Mironova L.G. orcid.org/0000-0002-2176-1090 Milyukov V.A. orcid.org/0000-0002-8069-457X The authors declare no conflict of interests Received April 24, 2021

\author{
Gins V.K. orcid.org/0000-0002-7053-4345 \\ Gins M.S. orcid.org/0000-0001-5995-2696 \\ Kononkov P.F. orcid.org/0000-0001-7101-3528 \\ Babayev V.M. orcid.org/0000-0002-3918-7031 \\ Pivovarov V.F. orcid.org/0000-0003-1350-5852
}

doi: 10.15389/agrobiology.2021.3.591eng

Abstract

Polysaccharides are one of the most important classes of natural compounds that have practical application in various fields of science and technology. Pectin remains one of the most 
essential polysaccharides, being a primary constituent of the structural elements of the cell wall in higher plants, performs the functions of binding and strengthening components of the cell wall, and also regulates water metabolism. Pectic substances are widely used in medicine as detoxicants of heavy metals and regulators of metabolic processes in the human body. In addition, they are also a universal food additive (E440). Despite significant amounts of traditional raw material resources (apple and citrus pomace, beet pulp), new alternative sources of raw materials are being searched for, including vegetable plants introduced in Russia for the production of pectins and their use in the production of functional foods. Among non-traditional plant resources, amaranth (Amaranthaceae) holds a significant rank. Due to its high yield and high content of biologically active substances and antioxidants, this crop acts as a potential source of obtaining valuable plant-derived substances for medicine, agriculture and the food industry. The Amaranthus tricolor L. cv. Valentina plants were used to isolate pectic substances by the classical method and ultrasonic treatment at a frequency of $22 \mathrm{kHz}$. Sugars were quantified using a Shimadzu 20-AD Prominence liquid chromatograph (Shimadzu Corporation, Japan) with a Shimadzu RID-10A refractometric detector. Infrared spectra were recorded on an IRS-113 instrument (Bruker, Germany) with a resolution of $1 \mathrm{~cm}^{-1}$ in the range 400-4000 $\mathrm{cm}^{-1}$. The elemental composition was determined (a CHNSO-high-temperature analyzer Euro EA 3028-HT-OM, EuroVector Instruments \& Software, Italy). All measurements by atomic force microscopy (AFM) were carried out on a Multi Mode V scanning probe microscope (Veeco Instruments, Inc., USA) in an intermittent contact mode. Structural study of the isolated polysaccharides by the IR spectroscopy method showed their possible affiliation to pectin substances. To study the monosaccharide composition, the samples of pectins were hydrolyzed with sulfuric acid ( $2 \mathrm{~N}$ ) and partially hydrolyzed with trifluoroacetic acid (TFA). The high-performance liquid chromatography (HPLC) identified glucose, galactose, rhamnose, arabinose and galacturonic acid in the pectin fractions. Low galacturonic acid contents of $0.63 \%$ and $1.68 \%$ were determined in $\mathrm{H}_{2} \mathrm{SO}_{4}$ and TFA hydrolyzates, respectively. The conditions for hydrolysis-extraction which ensure the maximum yield of pectin substances were $0.5 \%$ oxalic acid with complexone $\left(0.5 \%\right.$ HDTA), $50-55{ }^{\circ} \mathrm{C}$, $4 \mathrm{~h}$, feed to extractant volume (hydromodule) ratio of 1:15. The physicochemical properties of pectin obtained under these conditions were studied using atomic force microscopy (AFM) and thermogravimetric/differential scanning calorimetry (TG/DSC) methods. After ethanol re-precipitation, this pectin sample showed an intense absorption band of stretching vibrations of carbonyls of carboxyl groups and ester groups at $1742 \mathrm{~cm}^{-1}$. The TG/DSC indicated a two-step weight loss. The Fourier-transform infrared (FTIR) spectrum of the gaseous products derived from thermal decomposition of pectin sample showed that water was the main component of the gas phase at the first stage of weight loss and at the second stage, pectin was decarboxylated. According to atomic force microscopy, the size of the aggregates was 2.4-2.5 $\mu \mathrm{m}$ maximum and $\sim 330 \mathrm{~nm}$ minimum.

Keywords: Amaranthus tricolor L., amaranth, cv. Valentina, hydrolysis-extraction, ultrasonic disintegrator, pectin, IR spectroscopy, pectin thermostability, TG/DSC, AFM.

\section{REFEREN CES}

1. Komissarenko S.N., Spiridonov V.N. Rastitel'nye resursy, 1998, 34(1): 111-119 (in Russ.).

2. Samout N., Bouzenna H., Dhibi S., Ncib S., ElFeki A., Hfaiedh N. Therapeutic effect of apple pectin in obese rats. Biomedicine \& Pharmacotherapy, 2016, 83: 1233-1238 (doi: 10.1016/j.biopha.2016.08.038).

3. Yuliarti O., Goh K.K.T., Matia-Merino L., Mawson J., Brennan Ch. Extraction and characterisation of pomace pectin from gold kiwifruit (Actinidia chinensis). Food Chemistry, 2015, 187: 290-296 (doi: 10.1016/j.foodchem.2015.03.148).

4. Methacanon P., Krongsin J., Gamonpilas C. Pomelo pectin: effects of extraction parameters and its properties. Food Hydrocolloids, 2014, 35: 383-391 (doi: 10.1016/j.foodhyd.2013.06.018).

5. Minzanova S.T., Mironov V.F., Konovalov A.I., Vyshtakalyuk A.B., Tsepaeva O.V., Mindubaev A.Z., Mironova L.G., Zobov V.V. Pektiny iz netraditsionnykh istochnikov: tekhnologiya, struktura, svoistva i biologicheskaya aktivnost' [Pectins from unconventional sources: technology, structure, properties, and biological activity]. Kazan', 2011 (in Russ.).

6. Gins M., Gins V., Momyleva, S., Kulikov I., Medvedev S., Kononkov P., Pivovarov V. Mineral composition of amaranth (Amaranthus L.) seeds of vegetable and grain usage by ARHIVBSP selection. Potravinarstvo Slovak Journal of Food Sciences, 2018, 12(1): 330-336 (doi: 10.5219/863).

7. Vysochina G.I. Khimiya rastitel'nogo syr'ya, 2013, 2: 5-14 (in Russ.).

8. Magomedov I.M. Uspekhi sovremennogo estestvoznaniya, 2008, 5: 57-59 (in Russ.).

9. Ovodov Yu.S. Acta Naturae, 2010, 2(5): 29-37 (in Russ.).

10. Caselato-Sousa V.M., Amaya-Farfán J. State of knowledge on amaranth grain: a comprehensive review. Journal of Food Science, 2012, 77(4): R93-R104 (doi: 10.1111/j.1750-3841.2012.02645.x).

11. Fritz M., Vecchi B., Rinaldi G.Yu., Añón M.C. Amaranth seed protein hydrolysates have in vivo and in vitro antihypertensive activity. Food Chemistry, 2011, 126(3): 878-884 (doi: 10.1016/j.foodchem.2010.11.065). 
12. Orsini Delgado M.C., Tironi V.A., Anon M.C. Antioxidant activity of amaranth protein or their hydrolysates under simulated gastrointestinal digestion. LWT - Food Science and Technology, 2011, 44(8): 1752-1760 (doi: 10.1016/j.lwt.2011.04.002).

13. Mendonça S., Saldiva P.H., Cruz R.J., Arêas J.A.G. Amaranth protein presents cholesterollowering effect. Food Chemistry, 2009, 116(3): 738-742 (doi: 10.1016/j.foodchem.2009.03.021).

14. Silva-Sánchez C., Barba de la Rosa A.P., Leon-Galván M.F., De Lumen B O., De LeonRodríguez A., González de Mejía E. Bioactive peptides in amaranth (Amaranthus hypochondriacus) seed. Journal of Agricultural and Food Chemistry, 2008, 56(4): 1233-1240 (doi: 10.1021/jf072911z).

15. Quiroga A.V., Barrio D.A., Anon M.C. Amaranth lectin presents potential antitumor properties. LWT - Food Science and Technology, 2015, 60(1): 478-485 (doi: 10.1016/j.lwt.2014.07.035).

16. Ofitserov E.N., Kostin V.I. Uglevody amaranta $i$ ikh prakticheskoe ispol'zovanie /Pod redaktsiei Yu.S. Ovodova [Amaranth carbohydrates and their practical use]. Ul'yanovsk. 2001 (in Russ.).

17. Minzanova S.T., Mironov V.F., Vyshtakalyuk A.B., Tsepaeva O.V., Mironova L.G., A.I. Konovalov. Pectic polysaccharides from the plant Amaranthus cruentus. Water-soluble complexes of amaranth pectin with macro- and microelements. Russian Chemical Bulletin, 2014, 63(9): 2142-2155 (doi: 10.1007/s11172-014-0712-6).

18. Pivovarov V.F., Gins M.S., Gins V.K. Innovative beverage production technologies based on Amaranth biomass. IOP Conference Series: Earth and Environmental Science, 2019, 395: 012090 (doi: 10.1088/1755-1315/395/1/012090).

19. Gins M.S., Gins V.K., Motyleva S.M., Kulikov I.M., Medvedev S.M., Pivovarov V.F., Mertvishcheva M.E. I Metabolites with antioxidant and protective functions from leaves of vegetable amaranth (Amaranthus tricolor L.). Sel'skokhozyaistvennaya biologiya [Agricultural Biology], 2017, 52(5): 1030-1040 (doi: 10.15389/agrobiology.2017.5.1030eng).

20. Sarkar R., Nandan C.K., Mandal S., Patra P., Das D., Islam S.S. Structural characterization of a heteropolysaccharide isolated from hot water extract of the stems of Amaranthus tricolor Linn. (Amaranthus gangeticus L.). Carbohydrate Research, 2009, 344(17): 2412-2416 (doi: 10.1016/j.carres.2009.09.014).

21. Filippov M.P. Practical infrared spectroscopy of pectic substances Author links open overlay panel. Food Hydrocolloids, 1992, 6(1): 115-142 (doi: 10.1016/S0268-005X(09)80060-X).

22. Nahar K., Kabir F., Islam P., Rahman Md.M., Al Mamun Md.A., Faruk Md., Subhan N., Rahman G.M.S., Reza H.M., Alam Md.A. Cardioprotective effect of Amaranthus tricolor extract in isoprenaline induced myocardial damage in ovariectomized rats. Biomedicine \& Pharmacotherapy, 2018, 103: 1154-1162 (doi: 10.1016/j.biopha.2018.04.151).

23. Jiménez-Aguilar D.M., Grusak M.A. Minerals, vitamin C, phenolics, flavonoids and antioxidant activity of Amaranthus leafy vegetables. Journal of Food Composition and Analysis, 2017, 58: 33-39 (doi: 10.1016/j.jfca.2017.01.005).

24. Cho E.-H., Jung H.-T., Lee B.-H., Kim H.-S., Rhee J.-K., Yoo S.-H. Green process development for apple-peel pectin production by organic acid extraction. Carbohydrate Polymers, 2019, 204: 97-103 (doi: 10.1016/j.carbpol.2018.09.086).

25. Golubev V.N., Shelukhina N.P. Pektin: khimiya, tekhnologiya, primenenie [Pectin: chemistry, technology, practical use]. Moscow, 1995 (in Russ.).

26. Golbargi F., Taghi Gharibzahedi S.M., Zoghi A., Mohammadi M., Hashemifesharaki R. Microwave-assisted extraction of arabinan-rich pectic polysaccharides from melon peels: optimization, purification, bioactivity, and techno-functionality. Carbohydrate Polymers, 2021, 256: 117522 (doi: 10.1016/j.carbpol.2020.117522).

27. Maran J.P., Swathi K., Jeevitha P., Jayalakshmi J., Ashvini G. Microwave-assisted extraction of pectic polysaccharide from waste mangopeel. Carbohydrate Polymers, 2015, 123: 67-71 (doi: 10.1016/j.carbpol.2014.11.072). 